\title{
Protective Effect of Ipomoea staphylina Against Cadmium-Induced Cardiotoxicity in Wistar Rats
}

\author{
Z. YANCHUN, JIN XUE, F. S. MOHAMMED ${ }^{1}$ AND WANG XUE*
}

Department of Cardiovascular Medicine, The First Affiliated Hospital of Jilin University, Changchun City, Jilin 130000, China, ${ }^{1}$ Department of Pharmacology, Calcutta Institute of Pharmaceutical Technology \& AHS, Uluberia, Howrah 711316, West Bengal, India

Yanchun et al.: Cardioprotective Effect of Ipomoea staphylina

\begin{abstract}
The present study was aimed to evaluate the protective effect of ethanolic extract of Ipomoea staphylina leaves against cadmium-induced cardiotoxicity in rats. Rats were segregated into four groups which included normal control, cadmium treated, $\mathrm{Cd}^{+}$Ipomoea staphylina $(200 \mathrm{mg} / \mathrm{kg})$ treated, and $\mathrm{Cd}^{+}$Ipomoea staphylina $(400 \mathrm{mg} / \mathrm{kg})$ treated. The cadmium treatment resulted in a significant increase in the activities of lactate dehydrogenase, creatine phosphokinase, serum glutamic oxaloacetic transaminase and serum glutamic pyruvic transaminase. Also, a significant increase in the levels of cholesterol, triglycerides, and low-density lipoprotein was noticed after cadmium treatment. On the other hand, high-density lipoprotein was significantly decreased following cadmium treatment. A significant decline in the activity of antioxidant enzymes was observed in cadmium intoxicated rats. Moreover, cadmium intoxicated rats resulted in significant increase in the levels of proinflammatory cytokines such as tumor necrosis factor alpha, interleukin 1 beta, and nitric oxide in the cardiac tissue. Supplementation of Ipomoea staphylina leaves extract to cadmium treated rats reversed most of the indices. The extract $(400 \mathrm{mg} / \mathrm{kg})$ revealed better protective effects by decreasing the activities of lactate dehydrogenase, creatine phosphokinase, serum glutamic oxaloacetic transaminase and serum glutamic pyruvic transaminase and improving the lipid profile. Besides, the extract also significantly improved the antioxidant enzymes activity and decreased the level of tumor necrosis factor alpha, interleukin 1 beta, and nitric oxide. Further, the histopathological study of heart supported the protective effects of Ipomoea staphylina leaves extract. The study, therefore, concludes that Ipomoea staphylina leaves extract holds a strong protective effect against cadmium-induced cardiotoxicity in rats.
\end{abstract}

Key words: Diclofenac sodium, ethylhexyl palmitate, microemulsion, release kinetics, topical delivery

Cadmium (Cd), has been confirmed as a potent cardiotoxic environmental heavy metal ${ }^{[1,2]}$. It has been widely reported to induce oxidative stress and membrane disturbances in cardiac myocytes ${ }^{[3]}$. The multiple ways of $\mathrm{Cd}$ exposure include smoking, diet, polluted water with $\mathrm{Cd}$ and occupational exposures in certain industries. The prime reason behind the reported cardiotoxic effect is its capability to get absorbed in population even at low-level chronic exposures. Secondly, Cd has a long half-life, ranging from 10 to $40 \mathrm{y}$, leading to long term in vivo accumulation that in turn causes multi-organ toxicities including the heart. The heart is one of the most targeted organs by $\mathrm{Cd}$ exposure and results in oxidative damage. The human's myocardial autopsy reports also confirmed the presence of high levels of $\mathrm{Cd}$ in the myocardium ${ }^{[4]}$. Moreover, multiple reports suggested a clear association of $\mathrm{Cd}$

*Address for correspondence E-mail: xiangpica811109@sina.com

January-February 2021 toxicity with cardiovascular diseases (CVD) like hypertension, atherosclerosis, stroke, and cardiac arrest ${ }^{[5]}$. However, there is a paucity of information about exact mechanisms responsible for $\mathrm{Cd}$ mediated cardiovascular toxicities $^{[6]}$.

Many researchers worldwide are focusing on the compounds with good antioxidant potential as $\mathrm{Cd}$ exposure ultimately leads to oxidative stress. So, this oxidative stress further results in the production of reactive oxygen species (ROS), the already established This is an open access article distributed under the terms of the Creative
Commons Attribution-NonCommercial-ShareAlike 3.0 License, which
allows others to remix, tweak, and build upon the work non-commercially,
as long as the author is credited and the new creations are licensed under
the identical terms

Accepted 23 January 2021

Revised 25 Ocotber 2020

Received 06 January 2020 Indian J Pharm Sci 2021;83(1):93-100 
prime factors for cardiotoxicity. In the present study, the protective effect of the ethanolic extract of Ipomoea staphylina has been explored against $\mathrm{Cd}$ induced cardiotoxicity. Ipomoea staphylina (Family: Convolvulaceae) is a perennial woody plant considered as an important medical plant in an Asian traditional medicine system.

It is commonly used for the treatments of liver diseases, purgation, stomach disorders, pain, inflammation, and rheumatism. Experimental studies on this plant revealed that it contains sitosteryl-3-O- $\beta$-D-glucoside and chiro deoxy inositol ${ }^{[7]}$. The leaves extract of this plant possesses analgesic ${ }^{[8]}$, anti-inflammatory ${ }^{[9]}$, antiulcer ${ }^{[10]}$, hepatoprotective ${ }^{[11,12]}$, antidiabetic ${ }^{[13]}$, nephroprotective $\mathrm{e}^{[11]}$, and in vitro antioxidant activities ${ }^{[12]}$. However, there is a paucity of information about its use as cardioprotective. Therefore, the present study has been planned to evaluate its protective potential against Cd-induced cardiotoxicity in rats.

\section{MATERIALS AND METHODS}

Cd was procured from Sigma Chemicals (United States of America (USA)). Lactate dehydrogenase (LDH), creatine phosphokinase (CPK), serum glutamic oxaloacetic transaminase (SGOT), serum glutamic pyruvic transaminase (SGPT), cholesterol, and triglycerides kits were obtained from Span Diagnostics, India. Tumor necrosis factor-alpha (TNF- $\alpha$ ), interlukin-1 beta (IL-1 $\beta$ ), and nitric oxide (NO) kits were procured from Sigma Chemicals (USA). All other chemicals were commercial products of analytical reagent grade.

\section{Collection and authentication of the plant:}

Leaves of Ipomoea staphylina were collected from forest area of Karnataka near to Bangalore. The Ipomoea staphylina plant taxonomically identified and authenticated by Dr. K. Karthigeyan at Central National Herbarium, Botanic Garden, Howrah, where the voucher specimen is conserved under the reference number SMF-01.

\section{Preparation of ethanolic extract of leaves:}

The leaves of Ipomoea staphylina were cleaned and dried under shade at room temperature for several days and powdered. The powder was defatted with petroleum ether (60-80 GR) for $72 \mathrm{~h}$ and then the dried powder was extracted with ethyl alcohol to get a yield of $10.20 \% \mathrm{w} / \mathrm{w}$ dried extract was stored at $4^{\circ}$ in a refrigerator ${ }^{[13]}$.

\section{Experimental animals:}

Male Wistar rats in the weight range of 180-200 g were procured from the central animal house, of the institute. Animals were housed in polypropylene cages on a $12 \mathrm{~h} \mathrm{~d} /$ night cycle at a temperature of $22 \pm 1^{\circ}$. They were housed in polypropylene cages under hygienic conditions in the departmental animal house. All the experimental procedures were performed according to the ethics committee of The First Affiliated Hospital of Jilin University (Ethics No. ZN-IRB-00I-08).

\section{Acute oral toxicity:}

Male Wistar rats were kept overnight fasting before drug administration. This was followed by administration of a single oral dose $(2000 \mathrm{mg} / \mathrm{kg})$ of ethanolic extract Ipomoea staphylina leaves. The diet intake of animals was withheld for 3-4 $\mathrm{h}$ and they were kept under observation. They were observed twice after the first 30 min after dosing, periodically during the first $24 \mathrm{~h}$ (with special attention during the first $4 \mathrm{~h}$ ) and daily thereafter for $14 \mathrm{~d}^{[14]}$.

\section{Experimental design:}

After $1 \mathrm{w}$ acclimatization, male Wistar rats were randomly divided into four groups $(n=6)$. The $\mathrm{Cd}$ solution was freshly prepared in normal saline before administration. Similarly, the suspension of the extract was freshly prepared in $0.3 \% \mathrm{w} / \mathrm{v}$ carboxymethyl cellulose (CMC) before administration.

Each group received the following treatment;

Group I: Served as control and received normal saline ( $1 \mathrm{ml} / \mathrm{kg}$; orally (p.o.)). Group II: Received only $\mathrm{Cd}$ $(5 \mathrm{mg} / \mathrm{kg}$; p.o.). Group III: Received co-treatment of ethanolic extract of Ipomoea staphylina $(200 \mathrm{mg} / \mathrm{kg}$; p.o.) and Cd (5 mg/kg; p.o.). Group IV: Received cotreatment of ethanolic extract of Ipomoea staphylina (400 mg/kg; p.o.) and Cd (5 mg/kg; p.o.).

The rats were exposed to the respective treatment as mentioned in the groups for $28 \mathrm{~d}$. On the $28^{\text {th }} \mathrm{d}$, rats fasted for $24 \mathrm{~h}$ and blood was drawn by cardiac puncture under ether anesthesia for various biochemical estimations. The animals were sacrificed by cervical decapitation and the heart was dissected out, immediately rinsed in ice-cold saline, and stored for further biochemical and histopathological analysis ${ }^{[15,16]}$.

\section{Biochemical analysis:}

LDH, CPK, SGOT, SGPT, cholesterol, triglycerides, and lipoproteins were estimated using commercial kits 
(Span Diagnostics, India) as per the manufacturer's manual.

\section{Endogenous antioxidants and pro-inflammatory cytokines content in the heart:}

Tris phosphate buffer $(50 \mathrm{mM}, \mathrm{pH} 7.4)$ was used to prepare heart tissue homogenates $(10 \% \mathrm{w} / \mathrm{v})$. The homogenate was centrifuged at $3000 \mathrm{rpm}$ for $10 \mathrm{~min}$ at $4^{\circ}$. The supernatant was used to estimate lipid peroxidation (LPO), superoxide dismutase (SOD), reduced glutathione $(\mathrm{GSH})$, and catalase $(\mathrm{CAT})^{[17-}$ ${ }^{20]}$. The levels of pro-inflammatory cytokines (TNF- $\alpha$ and IL1- $\beta$ ) and NO were estimated by commercially available enzyme-linked immunosorbent assay (ELISA) kits, according to the instructions of the manufacturer.

\section{Histopathological studies:}

For the histopathological study fresh heart tissue pieces of rats were fixed in formalin. Following an overnight fixation in formalin, the specimens were dehydrated in ascending grades of alcohol, cleared in benzene and embedded in paraffin wax. Blocks were made and 4-5 $\mu \mathrm{m}$ thick sections were double-stained with hematoxylin and eosin $(\mathrm{H} \& \mathrm{E})$ and which were observed under the light microscope.

\section{Statistical analysis:}

The statistical significance of the data has been determined using one-way analysis of variance (ANOVA) followed a multiple post hoc least significant difference test. The results are represented as mean \pm standard deviation (SD).

\section{RESULTS AND DISCUSSION}

The results obtained from various experiments conducted in this study are depicted in Table 1, Table 2, Table 3, Table 4 and fig. 1. The data from various treatment groups have been compared with the

TABLE 1: EFFECTS OF Ipomoea staphylina ON SERUM LDH, CPK, SGOT, SGPT IN Cd TREATED RATS

\begin{tabular}{lccccc}
\hline Groups & Treatment & LDH (U/l) & CPK (U/l) & SGOT (IU/I) & SGPT (IU/l) \\
\hline I & Normal control & $154.08 \pm 1.36$ & $40.26 \pm 0.87$ & $34.15 \pm 0.94$ & $58.33 \pm 1.12$ \\
II & Cd control & $422.02 \pm 1.13^{c}$ & $161.63 \pm 1.13^{c}$ & $181.83 \pm 2.51^{c}$ & $169.73 \pm 1.04^{c}$ \\
III & Cd+ Ipomoea staphylina $(200 \mathrm{mg} / \mathrm{kg})$ & $261.99 \pm 1.43^{\mathrm{b}, \mathrm{y}}$ & $86.19 \pm 1.32^{\mathrm{c}, \mathrm{y}}$ & $103.45 \pm 1.54^{\mathrm{c}, \mathrm{x}}$ & $91.98 \pm 1.18^{\mathrm{b}, \mathrm{y}}$ \\
IV & Cd+ Ipomoea staphylina $(400 \mathrm{mg} / \mathrm{kg})$ & $217.55 \pm 2.84^{\mathrm{b}, \mathrm{y}}$ & $75.24 \pm 1.36^{\mathrm{b}, \mathrm{x}}$ & $82.69 \pm 1.78^{\mathrm{c}, \mathrm{z}}$ & $70.99 \pm 1.21^{\mathrm{a}, \mathrm{z}}$ \\
\hline
\end{tabular}

$\mathrm{n}=6$, Data are expressed in Mean $\pm S D,{ }^{a} \mathrm{p}<0.05,{ }^{b} \mathrm{p}<0.01$ and ${ }^{\mathrm{c}} \mathrm{p}<0.001$ by least significance difference test when values are compared with group I; ${ }^{x} p<0.05,{ }^{y} p<0.01$, and ${ }^{z} p<0.001$ by least significance difference test when values of groups III and IV are compared with group II

TABLE 2: EFFECTS OF Ipomoea staphylina ON CHOLESTEROL, TRIGLYCERIDES AND LIPOPROTEINS LEVELS IN Cd TREATED RATS

\begin{tabular}{lccccc}
\hline Groups & Treatment & $\begin{array}{c}\text { Cholesterol } \\
(\mathrm{mg} / \mathrm{dl})\end{array}$ & $\begin{array}{c}\text { Triglycerides } \\
(\mathrm{mg} / \mathrm{dl})\end{array}$ & $\begin{array}{c}\text { LDL } \\
(\mathrm{mg} / \mathrm{dl})\end{array}$ & $\begin{array}{c}\mathrm{HDL} \\
(\mathrm{mg} / \mathrm{dl})\end{array}$ \\
\hline I & Normal control & $54.08 \pm 1.36$ & $48.26 \pm 0.17$ & $9.15 \pm 0.34$ & $37.33 \pm 0.12$ \\
II & Cd control & $97.02 \pm 1.13^{\mathrm{c}}$ & $77.30 \pm 0.13^{\mathrm{b}}$ & $15.05 \pm 0.51^{\mathrm{a}}$ & $24.73 \pm 0.04^{\mathrm{b}}$ \\
III & Cd+ Ipomoea staphylina $(200 \mathrm{mg} / \mathrm{kg})$ & $68.99 \pm 0.43^{\mathrm{a}, \mathrm{x}}$ & $54.78 \pm 0.32^{\mathrm{x}}$ & $11.04 \pm 0.54^{\mathrm{a}, \mathrm{x}}$ & $30.98 \pm 0.18^{\mathrm{a}, \mathrm{x}}$ \\
IV & Cd+ Ipomoea staphylina $(400 \mathrm{mg} / \mathrm{kg})$ & $57.55 \pm 0.84^{\mathrm{y}}$ & $46.41 \pm 0.36^{\mathrm{y}}$ & $8.69 \pm 0.78^{\mathrm{y}}$ & $33.3 \pm 0.21^{\mathrm{y}}$ \\
\hline
\end{tabular}

$\mathrm{n}=6$, Data are expressed in Mean $\pm S D,{ }^{a} \mathrm{p}<0.05$, ${ }^{\mathrm{b}} \mathrm{p}<0.01$, and ${ }^{\mathrm{c}} \mathrm{p}<0.001$ by least significance difference test when values are compared with normal control group; ${ }^{x} p<0.05$ and ${ }^{y} p<0.01$ by least significance difference test when values of groups III and IV are compared with group II

TABLE 3: EFFECTS OF Ipomoea staphylina ON ANTIOXIDANT DEFENSE SYSTEM ENZYMES AND LPO IN Cd TREATED RATS

\begin{tabular}{|c|c|c|c|c|c|}
\hline Groups & Treatment & $\begin{array}{l}\text { LPO (n mol of MDA } \\
\text { formed } / \mathrm{min} / \mathrm{mg} \\
\text { protein) }\end{array}$ & $\begin{array}{l}\text { SOD } \\
\text { (IU) }\end{array}$ & $\begin{array}{l}\text { GSH }(\mu g / m g \text { of } \\
\text { protein) }\end{array}$ & $\begin{array}{c}\text { CAT } \\
\left(\mu \text { mol } \mathrm{H}_{2} \mathrm{O}_{2} / \mathrm{mg} \text { of }\right. \\
\text { protein })\end{array}$ \\
\hline I & Normal control & $1.08 \pm 1.36$ & $17.96 \pm 0.17$ & $15.75 \pm 0.34$ & $2.33 \pm 0.12$ \\
\hline II & Cd control & $2.91 \pm 0.31^{c}$ & $8.30 \pm 0.13^{c}$ & $8.08 \pm 0.51^{c}$ & $1.43 \pm 0.40^{c}$ \\
\hline III & $\begin{array}{c}\text { Cd+ Ipomoea staphylina } \\
(200 \mathrm{mg} / \mathrm{kg})\end{array}$ & $1.51 \pm 1.43^{b, y}$ & $12.78 \pm 0.32^{\mathrm{a}, \mathrm{y}}$ & $12.04 \pm 0.54^{a, y}$ & $1.70 \pm 0.18^{\mathrm{b}, \mathrm{x}}$ \\
\hline IV & $\begin{array}{c}\text { Cd+ Ipomoea staphylina } \\
(400 \mathrm{mg} / \mathrm{kg})\end{array}$ & $1.05 \pm 0.84^{a, z}$ & $14.41 \pm 0.3^{a, y}$ & $14.69 \pm 0.78^{y}$ & $2.09 \pm 0.21^{a, y}$ \\
\hline
\end{tabular}

$\mathrm{n}=6$, Data are expressed in Mean $\pm S D,{ }^{a} \mathrm{p}<0.05,{ }^{b} \mathrm{p}<0.01$, and ${ }^{\mathrm{c}} \mathrm{p}<0.001$ by least significance difference test when values are compared with group I; ${ }^{x} p<0.05,{ }^{y} p<0.01$, and ${ }^{\mathrm{z}} \mathrm{p}<0.001$ by least significance difference test when values of groups III and IV are compared with group 
www.ijpsonline.com

TABLE 4: EFFECTS OF Ipomoea staphylina ON HEART TNF-A, IL-1 $\beta$, AND NO IN Cd TREATED RATS

\begin{tabular}{|c|c|c|c|c|}
\hline Groups & Treatment & $\begin{array}{c}\text { TNF-a } \\
\text { ( } \rho g / m g \text { tissue) }\end{array}$ & $\begin{array}{c}\text { IL-1B } \\
\text { (pg/mg tissue) }\end{array}$ & $\begin{array}{c}\text { NO } \\
\text { ( } \rho g / m g \text { tissue) }\end{array}$ \\
\hline I & Normal control & $26.08 \pm 1.36$ & $23.26 \pm 0.17$ & $15.15 \pm 0.34$ \\
\hline II & Cd control & $117.02 \pm 1.13^{c}$ & $53.30 \pm 0.11^{c}$ & $46.05 \pm 0.51^{c}$ \\
\hline III & Cd+ Ipomoea staphylina (200 mg/kg) & $67.99 \pm 1.43^{c, y}$ & $40.78 \pm 0.32^{b, x}$ & $34.04 \pm 0.54^{c, x}$ \\
\hline IV & Cd+ Ipomoea staphylina (400 mg/kg) & $47.55 \pm 0.84^{\mathrm{b}, \mathrm{z}}$ & $32.41 \pm 0.36^{a, y}$ & $22.69 \pm 0.78^{a, y}$ \\
\hline
\end{tabular}

$\mathrm{n}=6$, Data are expressed in Mean $\pm S D,{ }^{a} \mathrm{p}<0.05$, ${ }^{b} \mathrm{p}<0.01$, and ${ }^{\mathrm{c}} \mathrm{p}<0.001$ by least significance difference test when values are compared with group I; ${ }^{x} p<0.05$, ${ }^{y} p<0.01$, and ${ }^{c} p<0.001$ by least significance difference test when values of groups III and IV are compared with group II

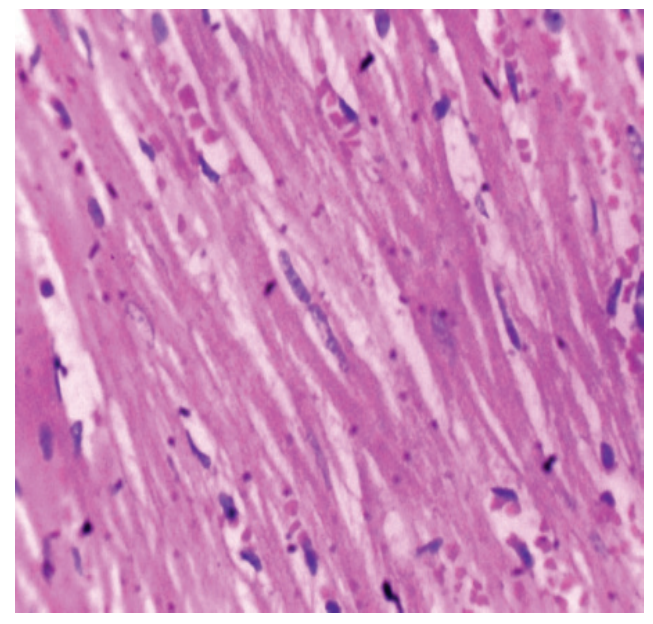

(A)

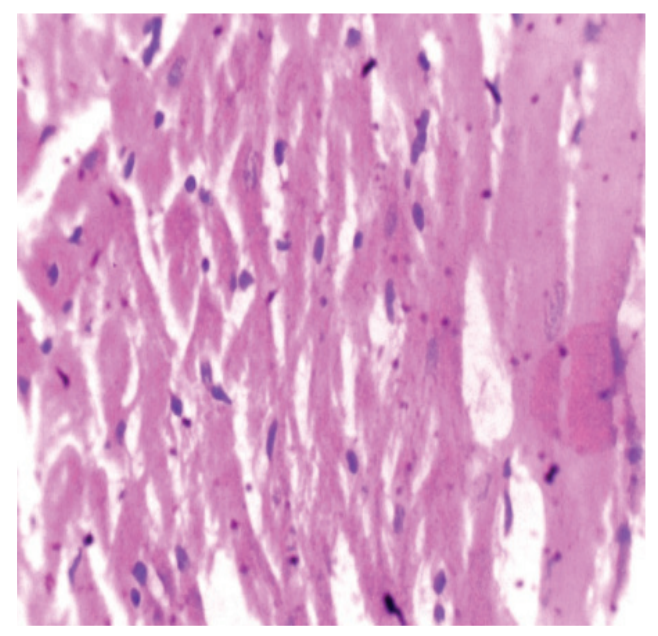

(C)

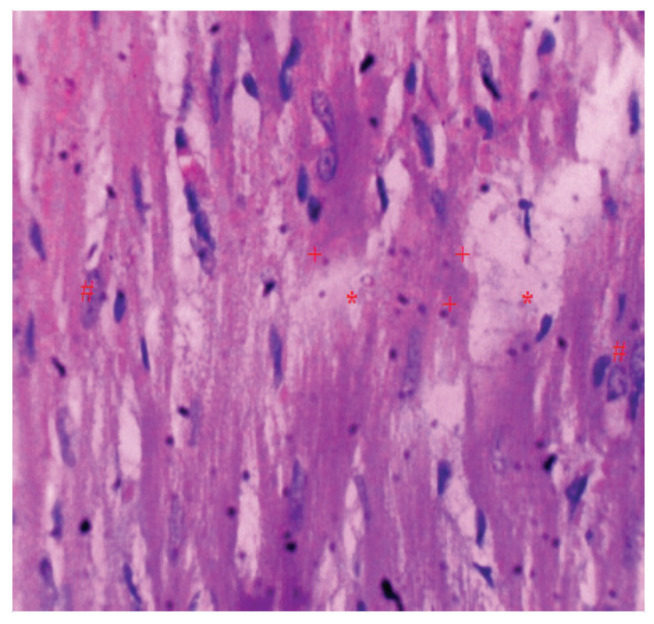

(B)

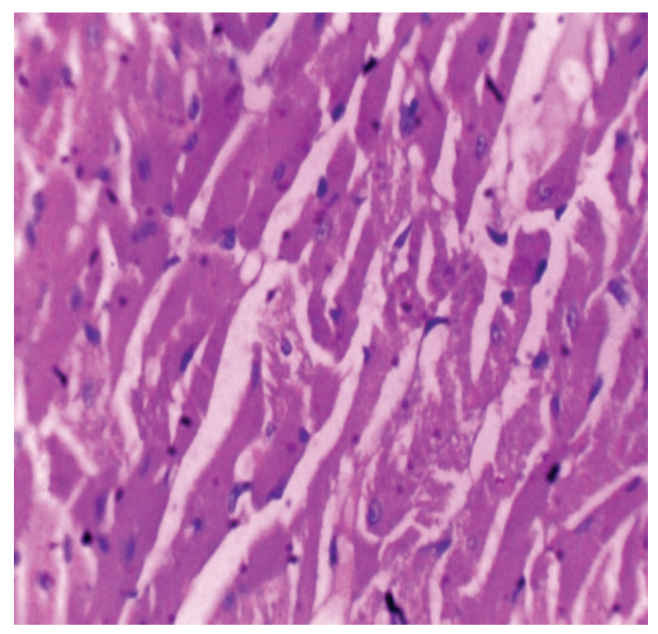

(D)

Fig. 1: Histopathological analysis of heart tissues of experimental animals

(A) Normal control: showing normal myocardial fibers with normal architecture (H\&E, 400x); (B) Cd control: showing degeneration and discontinuity of the hypertrophic myocardial fibers with infiltration of inflammatory cells and damaged nucleus (H\&E, 400x); (C) Cd+Ipomoea staphylina $(200 \mathrm{mg} / \mathrm{kg})$ : showing less degeneration and discontinuity of the myocardial fibers with mild infiltration of inflammatory cells $(\mathrm{H} \& \mathrm{E}, 400 \mathrm{x})$; (D) Cd+ Ipomoea staphylina $(400 \mathrm{mg} / \mathrm{kg})$ : showing almost normal heart tissue architecture (H\&E, 400x). * =damage discontinued muscle fibres; + =inflammatory cells; \# =damaged nucleus

normal control animals. Further, results obtained from group III and group IV animals were compared with that of Cd treated group II.

In the acute oral toxicity study, it was found that animals showed no changes in normal behaviour, signs of toxicity and mortality to a maximum dose of
$2000 \mathrm{mg} / \mathrm{kg}$. Thus, 200 and $400 \mathrm{mg} / \mathrm{kg}$ doses were considered in this study.

A statistically significant increase in the enzyme activity of LDH as well as CPK was observed in $\mathrm{Cd}$ treated rats (Table 1). Also, both SGOT and SGTP also showed a significant increase in their activities after 
treatment with $\mathrm{Cd}$. On the other hand, the ethanolic extract of Ipomoea staphylina leaves (200 and $400 \mathrm{mg}$ / $\mathrm{kg}$ ) resulted in a significant decrease in activities of all the above enzymes. Further, the modulatory potential was more prominent at a higher dose of the extract.

$\mathrm{Cd}$ treatment resulted in a significant increase in the levels of cholesterol, triglycerides, and low-density lipoprotein (LDL) (Table 2). On the other hand, highdensity lipoprotein (HDL) showed a significant decline after Cd treatment. Co-administration of the extract of Ipomoea staphylina (200 and $400 \mathrm{mg} / \mathrm{kg}$ ) significantly reduced the level of cholesterol, triglycerides, and LDL. Moreover, the extract significantly improved the level of HDL. The effect was more efficient at higher does $(400 \mathrm{mg} / \mathrm{kg})$.

A significant increase in the levels of LPO was observed in the cardiac tissues of $\mathrm{Cd}$ treated rats (Table 3). Besides, a significant decrease was observed in the levels of GSH as well as in the activities of SOD and CAT (Table 3) in the Cd treated group. Treatment with the extract of Ipomoea staphylina resulted in a significant decrease in LPO levels in Cd treated rats. Moreover, the extract also resulted in a significant improvement of the GSH levels and the activities of SOD and CAT.

$\mathrm{Cd}$ treatment resulted in a significant increase in the level of TNF- $\alpha$, IL-1 $\beta$, and NO (Table 4). Treatment with the extract of Ipomoea staphylina resulted in a significant decrease in the enzyme activities of all three indices. Further, the protective potential was more evident at a higher dose of ethanolic extract of Ipomoea staphylina.

Fig. 1 shows that sections of the normal heart (A) showing normal myocardial fibers with normal architecture. Rats intoxicated with $\mathrm{Cd}$ (B) showing degeneration and discontinuity of the hypertrophic myocardial fibers with infiltration of inflammatory cells. Section of the heart of rats treated with extract of Ipomoea staphylina (200 mg/kg) (C) showing less degeneration and discontinuity of the myocardial fibers with mild infiltration of inflammatory cells. Sections of the heart tissue of rats treated with the extract of Ipomoea staphylina (400 mg/kg) (D) showing almost normal heart tissue architecture.

The present study evaluated the protective effect of ethanolic extract of Ipomoea staphylina leaves against Cd-induced cardiotoxicity in Wistar rats. The study indicated that the administration of ethanolic extract of Ipomoea staphylina to the $\mathrm{Cd}$ treated animals appreciably modulated most of the biochemical indices along with histoarchitecture changes, which were altered due to toxic effects of $\mathrm{Cd}$ on cardiac tissues. All these improvements collectively contributed towards the protective effect of ethanolic extract of Ipomoea staphylina against $\mathrm{Cd}$-induced cardiotoxicity.

LDH is a marker of cardiac tissue injury including heart failure ${ }^{[21]}$ and it is recorded to be significantly elevated in the present study in $\mathrm{Cd}$ treated rats. Therefore, the above rise in $\mathrm{LDH}$ activity upon $\mathrm{Cd}$ treatment confirmed cardiac toxicity. Moreover, earlier reports on LDH are in corroboration with our results ${ }^{[22]}$. CPK is an enzyme responsible for the phosphorylation of creatine. High levels of CPK have been related to muscle injuries including heart muscles. In the present study, CPK showed a significant rise in Cd treated rats confirming injuries to heart muscles due to $\mathrm{Cd}$ toxicity. Also, a significant rise in SGOT and SGPT established $\mathrm{Cd}$ toxicity in the heart as these enzymes have been reported earlier in cardiac toxic states ${ }^{[23]}$. On the other hand, treatment with the extract of Ipomoea staphylina significantly reversed the effects of $\mathrm{Cd}$ and confirmed its protective effect. Moreover, the protective effects were more prominent at higher dose.

Alterations in the cholesterol levels, triglycerides and lipoproteins are considered as direct evidence of ill effects on heart health ${ }^{[24]}$. The present study showed significant changes, noticed in cholesterol, triglycerides, and lipoproteins. High LDL levels can cause the build-up of plaque leading to narrowing of the arteries that ultimately block the blood flow. Treatment with the extract of Ipomoea staphylina reversed the altered levels of cholesterol along with triglycerides. Naturally occurring phytosterols are well known for lipid-lowering activity ${ }^{[25]}$. Ipomoea staphylina has been reported to contain phytosterols like sitosteryl-3-O- $\beta$ D-glucoside ${ }^{[7]}$. Thus, the above lipid lowering effects could be a result of the presence of phytosterols in Ipomoea staphylina.

We observed a significant increase in LPO in the heart following Cd treatment. This is based on the appraisal of malondialdehyde (MDA) levels formed during the oxidative degradation of membranous polyunsaturated fatty acids. Interestingly, simultaneous treatment with ethanolic extract of Ipomoea staphylina to Cd treated animals showed moderation in the MDA levels that could be owed to their antioxidative nature and ability to scavenge $\operatorname{ROS}^{[26]}$. The observed increase in LPO is associated with a decrease in GSH levels as reduced 
glutathione is consumed by the glutathione related enzymes to detoxify peroxides formed by $\mathrm{LPO}^{[27,28]}$. Also, the sequestration of antioxidants like GSH is reported as an essential demand during toxic states. Besides, CAT is a free radical scavenging enzyme involves in detoxification of hydrogen peroxide ${ }^{[29]}$. It has been reported that an increase in hydrogen peroxide level might induce peroxidation of polyunsaturated fatty acids and increase the formation of MDA. The antioxidant enzyme, SOD is considered to be the primary enzyme as it is involved in the direct elimination of ROS. This enzyme works in coordination with other antioxidant enzymes to eliminate ROS. Also, it is a chain breaking antioxidant and plays an important role in protection against deleterious effects of $\mathrm{LPO}^{[30]}$. In the present study, SOD activity was found to be significantly decreased following $\mathrm{Cd}$ treatment which in turn promoted cardiac toxic effects by stimulating oxidative stress ${ }^{[31]}$. Treatment with Ipomoea staphylina extract decreased the levels of MDA and improved the activity of CAT and SOD. It is quite probable that Ipomoea staphylina supplementation made zinc available for the optimum functioning of the SOD against oxidative stress as phytochemicals have been reported to maintain normal zinc levels during oxidative stress $^{[32]}$.

TNF- $\alpha$ is an inflammatory cytokine that usually elevates in the cases of cardiotoxicity, has been demonstrated in experimental models ${ }^{[33]}$. In this study, a significant increase was noticed in TNF- $\alpha$ confirming the deleterious toxic effects of $\mathrm{Cd}$. The above rise in the TNF- $\alpha$ level may also involve in the inflammation of cardiac tissue. Moreover, IL-1 $\beta$ levels also showed a significant rise in the $\mathrm{Cd}$ treated rats. This IL- $1 \beta$ is also a direct indicator of inflammation. Heart failure patients have been demonstrated a marked elevation in a variety of inflammatory cytokines including IL- $1 \beta$ according to the degree of severity of the disease independent of etiology ${ }^{[34]}$. Hence, it is one of the crucial inflammatory markers. Further, NO levels also showed an elevation in the $\mathrm{Cd}$ treated rats. The observed rise in IL-1 $\beta$ could be responsible for this increase in NO levels as it has been reported earlier to cause an increase in the expression of Nitric Oxide Synthase (NOS) $)^{[35]}$. Besides, $\mathrm{NO}$ is a crucial regulator of heart contractility and rate. So, any alternation in NO levels significantly affects cardiac health. So, all the above changes proved cardiac toxicity induced by $\mathrm{Cd}$. Treatment with the extract of Ipomoea staphylina modulated above changes proving its anti-inflammatory ability.
Histological changes of $\mathrm{Cd}$ intoxicated heart tissue supported biochemical findings. Control animal slides showed normal architechture of cardiac muscle fibers. On the other hand, $\mathrm{Cd}$ treatment revealed significant signs of toxicity in the form of enlarged dark nuclei in the degenerated, discontinued and hypertrophic myocardial fibers with infiltration of inflammatory cells. Also, dilated ventricles and atria were visible confirming edema and fibrosis in the cardiac tissue ${ }^{[36]}$. Treatment with Ipomoea staphylina extract showed a marked improvement in the histoarchitecture of cardiac tissues. The signs of dilated ventricles and atria disappeared.

From this study, we came to know that $\mathrm{Cd}$ intoxication leads to an increase in oxidative stress and decreased the antioxidant defense specially GSH. It is known that GSH protects from oxidative assaults and it prevents the LPO and oxidized glutathione formation in the heart. It has been demonstrated that glucose-6phosphate dehydrogenase (G6PD) depletes cytosolic GSH levels and subsequently results in cardiomyocyte contractile dysfunction through dysregulation of calcium homeostasis which may be a reason for $\mathrm{Cd}$ induced cardiac dysfunction ${ }^{[37]}$. In our study, we found that the extract notably increased the level of GSH which could probably via inhibition of G6PD by the extract. Moreover, a literature survey reveals that oxidative stress and inflammatory cytokines are the major culprits to bring out the artifacts in cardiac tissue due to $\mathrm{Cd}$ exposure and thus the effect of the extract on oxidative stress and inflammatory markers in $\mathrm{Cd}$ intoxicated rats was studied. Inflammation resulting from oxidative stress is the major cause of cardiac disease. An increase in the oxidative stress causes activation of Nuclear factor kappa B (NF-kappa-B), one of the key signalling molecules, which is a transcription factor that up-regulates the production of downstream inflammatory mediators, including TNF- $\alpha$, IL-1 $\beta$, and $\mathrm{NO}^{[34,35]}$. However, we have evaluated the effect of the extract on endogenous antioxidants especially SOD, CAT, and GSH and inflammatory markers (Heart TNF- $\alpha$, IL-1 $\beta$, and NO). We found a noteworthy increase in antioxidative defense and a decrease in pro-inflammatory cytokines in the heart of $\mathrm{Cd}$ intoxicated animals due to the supplementation of the extract. Besides, the ability of Ipomoea staphylina treatment to restore the histological changes induced by $\mathrm{Cd}$ indicated its protective efficacy against $\mathrm{Cd}$. The present study, therefore, concludes that Ipomoea staphylina extract has got great protective potential against $\mathrm{Cd}$-induced cardiac toxicity. 
Our results demonstrated that ethanolic extract of Ipomoea staphylina showed cardioprotective activity against $\mathrm{Cd}$-induced cardiotoxicity in rats. The observed beneficial findings of this study may be credited to the antioxidant effect and suppression of TNF- $\alpha$, IL1- $\beta$ and $\mathrm{NO}$ in the heart tissue.

\section{Acknowledgements:}

None

\section{Conflict of Interests:}

The authors declared no conflict of interest.

\section{REFERENCES}

1. Akerstrom M, Barregard L, Lundh T, Sallsten G. The relationship between cadmium in kidney and cadmium in urine and blood in an environmentally exposed population. Toxicol Appl Pharmacol 2013;268(3):286-93.

2. Refaie MM, El-Hussieny M, Bayoumi AM, Shehata S. Mechanisms mediating the cardioprotective effect of carvedilol in cadmium induced cardiotoxicity. Role of eNOS and HO1/ Nrf2 pathway. Environ Toxicol Pharmacol 2019;70:103198.

3. Manoharan V, Miltonprabu S. Cadmium induced cardiac oxidative stress in rats and its attenuation by GSP through the activation of Nrf2 signaling pathway. Chem Biol Interact 2015;242:179-93.

4. Borne Y, Barregard L, Persson M, Hedblad B, Fagerberg B, Engstrom G. Cadmium exposure and incidence of heart failure and atrial fibrillation: a population-based prospective cohort study. BMJ open 2015;5(6):e007366.

5. Tellez-Plaza M, Guallar E, Howard BV, Umans JG, Francesconi $\mathrm{KA}$, Goessler W, et al. Cadmium exposure and incident cardiovascular disease. Epidemiology 2013;24(3):421-9.

6. Fagerberg B, Bergstrom G, Boren J, Barregard L. Cadmium exposure, intercellular adhesion molecule-1 and peripheral artery disease: a cohort and an experimental study. BMJ open 2013;3(3);e002489.

7. Reddy DP, Kota R, Renuka S, Anarthe SJ, Raghavendra NM. Isolation, characterization of phytoconstituents and pharmacological screening of Ipomoea staphylina. Asian J Pharm Clin Res 2013;6(1):30-3.

8. Ghosh S, Firdous SM. Evaluation of analgesic activity of hydroalcoholic extract of Ipomoea staphylina. Thai J Pharm Sci 2014;38(2):57-60.

9. Firdous SM, Koneri R. In vivo and in vitro antiinflammatory activity of leaves of Ipomoea staphylina. Int J Pharm Pharm Sci 2012;4(5):339-43.

10. Banerjee A, Firdous SM. Antiulcer activity of hydroalcoholic extract of Ipomoea staphylina plant in rats. Bangladesh J Pharmacol 2015;10(3):652-3.

11. Bag AK, Mumtaz SF. Hepatoprotective and nephroprotective activity of hydroalcoholic extract of Ipomoea staphylina leaves. Bangladesh J Pharmacol 2013;8(3):263-8.

12. Ramachandran J, Arul AD, Thilagar S. Hepatoprotective and antioxidant activity of Ipomoea staphylina Linn. Clin Phytoscience 2019;5(1):1-11.

13. Firdous SM, Koneri R. Antidiabetic and antioxidant activities of Ipomoea staphylina Leaves in streptozotocin (STZ) induced diabetic mice. J PharmaSciTech 2014;3(2);77-84.
14. OECD, 2002. Acute oral toxicity. Acute oral toxic class method guideline 423 adopted 23.03.1996. In: Eleventh Addendum to the OECD guidelines for the testing of chemicals. Organisation for economic co-operation development, Paris; 2000.

15. Priya LB, Baskaran R, Elangovan P, Dhivya V, Huang CY, Padma VV. Tinospora cordifolia extract attenuates cadmiuminduced biochemical and histological alterations in the heart of male Wistar rats. Biomed Pharmacother 2017;87:280-7.

16. Zhang D, Hou L, Peng W. Tangeritin attenuates oxidative stress, apoptosis and inflammation in cadmium-induced cardiotoxicity in rats by activating Nrf2 signaling pathway. Trop J Pharm Res 2018;17(12):2421-6.

17. Ohkawa H, Ohishi N, Yagi K. Assay for lipid peroxides in animal tissues by thiobarbituric acid reaction. Anal Biochem 1979;95(2):351-8.

18. Rotruck JT, Pope AL, Ganther HE, Swanson AB, Hafeman DG, Hoekstra W. Selenium: biochemical role as a component of glutathione peroxidase. Science 1973;179(4073):588-90.

19. Marklund S, Marklund G. Involvement of the superoxide anion radical in the autoxidation of pyrogallol and a convenient assay for superoxide dismutase. Eur J Biochem 1974;47(3):469-74.

20. Sinha AK. Colorimetric assay of catalase. Anal Biochem 1972;47(2):389-94.

21. Augoff K, Hryniewicz-Jankowska A, Tabola R. Lactate dehydrogenase 5: an old friend and a new hope in the war on cancer. Cancer Lett 2015;358(1):1-7.

22. Zhuang J, Nie G, Yang F, Dai X, Cao H, Xing C, et al. Cadmium induces cytotoxicity through oxidative stressmediated apoptosis pathway in duck renal tubular epithelial cells. Toxicol In Vitro. 2019 Dec 1;61:104625.

23. Bhattacharjee B, Ghosh AK, Mishra S, Das J, Chattopadhyay A, Bandyopadhyay D. Terminalia arjuna aqueous bark extract protects against cadmium acetate-induced injury to rat liver and heart through antioxidant mechanisms: a dose response study. J Pharma Res 2016;10:771-92.

24. Malta DC, Szwarcwald CL, Machado IE, Pereira CA, Figueiredo AW, Sa ACMGN, et al. Prevalence of altered total cholesterol and fractions in the Brazilian adult population: National Health Survey. Rev Bras Epidemiol 2019;22(02):E190005.

25. Marangoni F, Poli A. Phytosterols and cardiovascular health. Pharmacol Res 2010;61(3):193-9.

26. Leonard SS, Xia C, Jiang BH, Stinefelt B, Klandorf H, Harris $\mathrm{GK}$, et al. Resveratrol scavenges reactive oxygen species and effects radical-induced cellular responses. Biochem Biophys Res Commun 2003;309(4):1017-26.

27. Sreedharan V, Venkatachalam KK, Namasivayam N. Effect of morin on tissue lipid peroxidation and antioxidant status in 1, 2-dimethylhydrazine induced experimental colon carcinogenesis. Invest New Drugs 2009;27(1):21-30.

28. Velmurugan B, Bhuvaneswari V, Burra UK, Nagini S. Prevention of N-methyl-N'-nitro-N-nitrosoguanidine and saturated sodium chloride-induced gastric carcinogenesis in Wistar rats by lycopene. Eur J Cancer Prev 2002;11(1):19-26.

29. Salminen A, Vihko V. Lipid peroxidation in exercise myopathy. Exp Mol Pathol 1983;38(3):380-8.

30. Dinkova-Kostova AT. Protection against cancer by plant phenylpropenoids: induction of mammalian anticarcinogenic enzymes. Mini Rev Med Chem 2002;2(6):595-610.

31. Janssen AM, Bosman CB, Kruidenier L, Griffioen G, Lamers $\mathrm{CB}$, Van Krieken JH, et al. Superoxide dismutases in the human colorectal cancer sequence. J Cancer Res Clin Oncol 1999;125(6):327-35.

32. Antal DS, Vlaia V, Dehelean CA, Vlaia L, Trandafirescu C, 
Ardelean F, et al. Zinc across medicinal plants from Romanian biodiversity and the implications for human health. Rev Chim 2015;66(2):236-9.

33. Shaker RA, Abboud SH, Assad HC, Hadi N. Enoxaparin attenuates doxorubicin induced cardiotoxicity in rats via interfering with oxidative stress, inflammation and apoptosis. BMC Pharmacol Toxicol 2018;19(1):1-10.

34. Yndestad A, Damas JK, Oie E, Ueland T, Gullestad L, Aukrust P. Systemic inflammation in heart failure-the whys and wherefores. Heart Fail Rev 2006;11(1):83-92.

35. Tatsumi T, Matoba S, Kawahara A, Keira N, Shiraishi J,
Akashi $\mathrm{K}$, et al. Cytokine-induced nitric oxide production inhibits mitochondrial energy production and impairs contractile function in rat cardiac myocytes. J Am Coll Cardiol 2000;35(5):1338-46.

36. Gudenschwager EK, Abbott JA, LeRoith T. Dilated cardiomyopathy with endocardial fibroelastosis in a juvenile Pallas cat. J Vet Diagn Invest 2019;31(2):289-93.

37. Jain M, Brenner DA, Cui L, Lim CC, Wang B, Pimentel DR, et al. Glucose-6-phosphate dehydrogenase modulates cytosolic redox status and contractile phenotype in adult cardiomyocytes. Circ Res 2003;93(2):e9-16. 